\title{
NURSES WORKLOAD COMPARISON BETWEEN VOLUNTARY NURSES AND GOVERNMENT EMPLOYEE NURSES
}

\author{
Hotma Royani Siregar $^{1 *}$, Febrina Angraini Simamora ${ }^{2}$ \\ ${ }^{1,2}$ Universitas Aufa Royhan Padangsidimpuan \\ Email*: hotma_srg@yahoo.com
}

\begin{abstract}
Introduction: Padangsidimpuan General Hospital is a hospital owned by the Padangsidimpuan City government which employs Voluntary Nurses and government Employee Nurses. The purpose of this study is to determine the workload comparison of Voluntary Nurses and Government Employee Nurses. Methods: Research was conducted using quantitatif and qualitative methods using observation techniques work sampling, and interview guidelines. Partisipant has been observed were 15 Voluntary Nurses and 15 Government Employee nurses who are on duty at that time by using accidental sampling technique. Samples taken were all activities carried out by Voluntary Nurses and Government Employee Nurses, such as direct nursing activities, indirect nursing activities, personal activities, and non-productive activities. Results: The results of observations and interviews described there is difference between workload of voluntary nurses with government employee nurses. After analysed using Collaizi's Methode and The mannwhitney test on the workload of nurses Voluntary Nurses and Government Employee Nurses found a significant difference with the value of $p=0.0001(p<0.05)$ which means there is a difference in workload between Voluntary Nurses and Government Employee Nurses. With the workload on Voluntary nurses amounted to 74.8\%, while the Government Employee nurses amounted to $69.6 \%$. The results of the study suggest that the management of Padangsidimpuan General Hospital to manage nursing staff optimally to achieve quality nursing services. Conclusions: There is difference in workload between Voluntary nurses and government employee nurses.
\end{abstract}

Keywords: government employee nurses; voluntary nurses; workload

\section{INTRODUCTION}

Nurse workload is all activities or activities carried out by a nurse while serving in a nursing service unit Marquis and Houston (2000). Workload (work load) is usually interpreted as patient days that refer to the number of procedures, visiting client. Workload is the total amount of nursing time both directly / indirectly in providing nursing services needed by the client and the number of nurses needed to provide these services (Gaudine, 2000).

Padangsidimpuan General Hospital is a government hospital that has two kinds of workers. There are voluntary nurses and government employee nurses. Voluntary Nurse is a health worker who are willing to provide health services to clients who need them in health care centers both in hospitals and in health centers without expecting anything in return (Siregar, 2015). While government employee nurse is working with salary that they can recieve every month.

Based on a preliminary survey at Padangsidimpuan General Hospital, 90 data of nurses working in hospitals were divided into several rooms in the hospital. Based on The results of a short interview, that voluntary nurses always spending time more than government employee nurses. Government employee nurses always asking help from voluntary nurses to finish their work. While voluntary nurses can not refuse the request from government employee nurses. Like voluntary nurses's statements: "Already the nature of the voluntary nurses a lot of work. We all know that voluntary nurses work harder than employees. And "In any room in this hospital voluntary nurses more tired". The Government employee nurses said that sometimes they asked help from voluntary nurses to finish their work. Based on the background above the researcher will wants to know nurses workload comparison between voluntary nurses and government employee nurses.

The aim of this study is to compare workload between voluntary nurses and government employee nurses.

\section{METHODS}

This study uses quantitative and qualitative research using observation and interview techniques to obtain the required data. The technique used in observation is to get a comparison between the workloads of voluntary nurses and Government Employee nurses using work sampling techniques. Where observed voluntary nurses and Government Employee Nurses were examined every five minutes for 
one working day. Participants used in this study were 30 nurses consisting of 15 voluntary nurses and 15 Government Employee Nurses. The Participant Characteristics were voluntary nurses and government employee nurses working in morning shift, working more than two years and agree become a partisipant for this research.

The tools used to make observations are the work sampling form (Ilyas, 2004) which contains the observation time, the activities of nurses consisting of direct nursing activities, indirect nursing activities, personal activities and non-productive activities, whatc and stationery to assist in recording nursing activities. Observations are made for 1 shift in one working day. In addition to interview guides, field notes are also a tool used for data collection in this study. Another data collection tool used in this study is a voice recorder (tape recorder), where this tool will be used to record the results of interviews. The trasncript will be analyed using Collaizi's Methode (Collaizi, 1978 in Strubert \& Carpenter, 2011). Base on the research, the title in this research accordance with the objectives and research methods.

\section{RESULTS}

From table 1, most of the sex participants were women with a total of 12 people $(80 \%)$ voluntary nurses and 11 people (73.3\%) Government Employee Nurses, for most participants education with a total of 7 people $(46.7 \%)$ D III Nursing, and 8 people ( $53.5 \%$ ) Nurse, while the age of participants for voluntary nurses averaged 27.3 and Government Employee Nurses averaged 41.5

Table 2 shows that the use of time for voluntary nurses activities is more than for Government Employee Nurses. Voluntary nurses use an average time of 381.5 minutes for seven working hours on the morning shift and Government Employee nurses Nurses an average of 314.8 minutes. For direct nursing activities voluntary nurses use 167.9 minutes (43.9\%), while Government Employee Nurses 150.1 minutes $(41.6 \%$. For indirect nursing activities voluntary nurses use 118.4 minutes (31.1) \%), while the average Government Employee Nurses was 101.2 (28\%). In personal activities the voluntary nurses used an average time of 57.2 minutes $(69.7 \%)$, and the average Government Employee Nurses was 60.7 minutes $(16.8 \%)$ In non-productive activities, Voluntary nurses use an average time of 38.9 minutes (10.3\%) and Government Employee Nurses an average of 49.2 minutes (13.6\%). with Government Employee Nurses which is an average of 67.7 minutes.

The results of the analysis of table 3 can be concluded that on average After a significant test using the mannwhitney test on the workload of voluntary nurses and Government Employee Nurses found a significant difference with the value of $\mathrm{p}=$ 0.0001 ( $\mathrm{p}<0.05)$, which means there are differences workload between voluntary nurses and Government Employee Nurses.

The results of interviews with nurses Voluntary and Government Employee Nurses, obtained results that productive and nonproductive nursing activities are almost the same as the statement of some participants below:

\section{Productive Activities (direct and indirect nursing activities)}

"If our jobs as a voluntary nurses same as the state Government Employee Nurses, it's the same for our job, for our patients per room it makes no difference, at least if the state Government Employee Nurses have experience so ... the person working on that person is faster. And sometimes they asked help from us.. please hahahah. (Voluntary Nurses).

"It's the same, ma'am, it doesn't make any difference between our work, already divided by the patient and the deadline, do each one's work, at least if it's busy next time with my patient, sometimes ask for help with me, the voluntary is not ... right? asking for help with the voluntary sisters "( Government Employee Nurses)

\section{Personal and Non-productive Activities}

"Our private activities are almost the same, ma'am, like eating, drinking, praying, resting in the room for a while, yes at least the same as the civil nurses, but sometimes Government Employee Nurses really like longer time for personal activities he bu" (voluntary nurse).

"There is no more work for patients and at 12 o'clock in the afternoon it must be hungry, yes we are eating, drink, then if we enter prayer time yes pray, that's our most 


\section{personal activity, (Government Employee Nurses)}

"If our activities besides patients play cellphones, call, chat in the nurse's room, sometimes go out of the room to buy food, yes sometimes watch $T V$ if there is no more work ,, (voluntary nurse)

"Watching TV, watching cellphones, chatting with friends, sometimes buying food in the future, sometimes going out for personal business," (Government Employee Nurses)

Unyvariat Analysis

Table 1 Participant Characteristics

\begin{tabular}{|c|c|c|c|c|}
\hline \multirow[t]{2}{*}{ Characteristics } & \multicolumn{2}{|c|}{ Voluntary Nurses } & \multicolumn{2}{|c|}{ Government Employee Nurses } \\
\hline & Frequency (n) & $\%$ & Frequency (n) & $\%$ \\
\hline \multicolumn{5}{|l|}{ Gender } \\
\hline Man & 3 & 20 & 4 & 26,7 \\
\hline Woman & 12 & 80 & 11 & 73,3 \\
\hline \multicolumn{5}{|l|}{ Education } \\
\hline Nursing Diploma & 7 & 46,7 & 2 & 11,5 \\
\hline Bachelor & 4 & 26,7 & 5 & 33,5 \\
\hline Ners & 4 & 26,7 & 8 & 53,3 \\
\hline \multirow{3}{*}{ Age } & \multicolumn{4}{|c|}{ Mean } \\
\hline & Voluntary $\mathrm{N}$ & \multicolumn{3}{|c|}{ Government Employee Nurses } \\
\hline & 27,3 & \multicolumn{3}{|c|}{41,5} \\
\hline
\end{tabular}

Table 2 Total Uses of Work Time Voluntary Nurses and Government Employee Nurses Using the Work Sampling Methods

\begin{tabular}{|c|c|c|c|c|}
\hline \multirow{4}{*}{ Nurses Activity } & \multicolumn{4}{|c|}{ Mean } \\
\hline & \multirow{3}{*}{$\begin{array}{c}\text { Voluntary Nurses } \\
\text { Minute (day) }\end{array}$} & \multicolumn{3}{|c|}{ Government } \\
\hline & & $\%$ & Employee Nurses & $\%$ \\
\hline & & & Minute (day) & \\
\hline Work Load (minute) & 381,5 & 100 & 314,8 & 100 \\
\hline direct nursing activities & 167,9 & 43,9 & 150,1 & 41,6 \\
\hline indirect nursing activities & 118,4 & 31,1 & 101,2 & 28 \\
\hline personal activities & 57,2 & 69,7 & 60,7 & 16,8 \\
\hline non-productive activities & 38,9 & 10,3 & 49,2 & 13,6 \\
\hline
\end{tabular}

Bivariate Analysis

Table 3. Bivariate Analysis

\begin{tabular}{l} 
Variable \\
\hline Voluntary Nurses Workload \\
\hline Government Employee Nurses Workload \\
DISCUSSIONS \\
$\quad$ According to Gillies (1994), nursing \\
activities are generally divided into 4 activities,
\end{tabular}
namely direct activities, indirect activities, unit activities and personal activities. Some opinions of previous researchers and experts expressed their opinions regarding the use of standard time working time for workload which will be

\begin{tabular}{ccc}
$\mathbf{N}$ & mean & Pvalue \\
\cline { 2 - 2 } 15 & $\mathbf{3 8 1 , 5}$ & $0,0001^{*}$ \\
\hline
\end{tabular}

linked to the discussion of the results of this study.

The results showed that nursing activities with the most use of time were voluntary nurses with an average time of 382.5 minutes or $74.8 \%$ while nurses Government Employee Nurses 314.8 minutes or $69.6 \%$. In productive activities between direct and indirect activities are not so much different where in carrying out nursing care both directly related to patients and those that are not directly related 
is almost balanced because the mobility between direct and indirect activities is almost equal.

Based on the analysis results contained in table 3 above it can be concluded that on average After a significant test was performed using the mannwhitney test on the workload of nurses and Government Employee nurses found a significant difference with the value of $\mathrm{p}=0,0001(\mathrm{p}<0.05)$ which means there is a difference in workload between voluntary nurses and Government Employee nurses. The workload of voluntary nurses is greater than that of Government Employee nurses due to the ability of Government Employee nurses to perform nursing activities better, this is due to the Government Employee nurses who are more experienced in providing nursing care to patients Padangsidimpuan General Hospital. However, based on the results of interviews with several participants voluntary nurses stated that Government Employee nurses sometimes increase the workload of voluntary nurses by asking voluntary nurses to help complete the nursing activities of Government Employee nurses both direct nursing activities and indirect nursing activities.

Voluntary nurses and Government Employee Nurses have productive work time that is not much different, with productive work time below $80 \%$. Thus, according to Ilyas (2000) in Eros (2006) based on the available time, productive work time at the optimum point is around $80 \%$. Whereas Syamsi (1998) in Eros (2006), the standard time for productive activities is $75 \%$ and Heizer and Render (1996) in Eros (2006) is that the standard time for productive activities is $80 \%$, whereas according to Wolper (2001) $85 \%$.

\section{CONCLUSIONS}

Based on the background of the problem, objectives, research results and discussions that have been described previously. The conclusion of this research is There is difference of workload between voluntary nurses and Government Employee nurses in Padangsidimpuan General Hospital.

\section{SUGGESTIONS}

\section{For Padangsidimpuan General Hospital}

Optimal management of nursing staff to achieve nursing services such as holding regular training related to nursing care activities. For the Head of Nursing

Calculate the average use of nursing activities to determine the workload of nurses using the work sampling format.

\section{For further researchers}

Conducting research by comparing the number of observants with those observed is 1 : 1 and calculating the average use of time of nursing activities directly when observed.

\section{REFFERENCES}

Eros, Syah, 2006. Analisis Beban Kerja Perawat dengan Menggunakan metode Work Sampling Pada Unit Rawat jalan Rumah Sakit Hai Jakarta. Tesis. Program Pascasarjana Pakultas Kesehatan masyarakat Universitas Indonesia.

Ilyas, Yaslis, 2013,. Perencanaan SDM Rumah Sakit. Fakultas Kesehatan Masyarakat Universitas Indonesia, Depok, Indonesia.

Gaudine, 2000, Measuring Nurse's Workload. $\mathrm{http} / \mathrm{www}$..cna-aiic.ca/CNA/documents/ pdf/publications//NN Nurses workload. Diakses pada tanggal 12 Maret 2018.

Gillies, D.A, 1996, Nursing Management : A System Approach. Third Edition Philadelphia : WB Saunders

Marquis, B.L. \& Houton, C.L, 2000, Management Decision Marking for Nurses. Philladelphia. Lippincott.

Meidiawati, Christine, 2012, Analisisi Beban Kerja Untuk Menentukan Kebutuhan Tenaga Perawat Dengan Work Load Indicator of Staffing Need (WISN) Di Instalasi Rawat Inap Flamboyan Rumah Sakit Tugu Ibu Tahun 2012. Universitas Indonesia. Jakarta

Siregar, H.R, 2015, Pengalaman Perawat Tenaga Kerja Sukarela Dalam Memberikan Pelayanan Kesehatan di Rumah Sakit Umum Daerah Padangsidimpuan (Tesis Magister Ilmu Keperawatan Universitas Sumatera Utara).

Streubert, H. J \& Carpenter, D. R. (2011). Qualitative research in nursing Advancing the humanistic imperative. (5th edition). Philadelphia: J.B. Lippincott \& Wilkins. 